\title{
Determination of the Elemental Composition of Lichens by Atomic Emission Spectrometry
}

\author{
Albina V. Stepanova*; Semen M. Timofeev; Aigerim Sh. Smagulova; \\ Dmitry M. Uvarov \\ North-Eastern Federal University named after M.K. Ammosov \\ Yakutsk, the Republic of Sakha, Russia
}

\begin{abstract}
This work represents the results of a determination of the elemental composition of lichen thallus as a promising, ecologically pure, and renewable raw material for biotechnological processing. The content of toxic elements and heavy metals in the samples analyzed does not exceed their maximum allowable concentrations and therefore does not preclude the possibility of use of these lichens as a renewable raw material for biotechnology. Indeed, the samples contained 20 macro- and microelements and 9 trace elements that would be valuable in a food source. These include the elements $\mathrm{Fe}, \mathrm{Mg}$, and $\mathrm{Ca}$, required for prevention of deficiency diseases. (Int J Biomed. 2015;6(1):85-86.).
\end{abstract}

Keywords: lichen; elemental analysis; biotechnology; emission spectromenry.

\section{Introduction}

In recent years the lichen blastema has been widely used as a valuable raw material for obtaining a series of biopreparations used in medicine, and in the veterinary and food industries [1-2].

The objective of this work was to study the elemental composition of two types oflichen thallus: Cladoniarangiferina (reindeer lichen) and Cetrariacuculata as a prospective raw material for use in biotechnology.

\section{Materials and Methods}

The lichens were collected in the summer from an area of their typical habitat, $30 \mathrm{~km}$ to the north of Yakutsk and $1.5 \mathrm{~km}$ away from any highway. The collected lichenoid raw material was dried in accordance with GOST-13727-68.

Solutions of the samples were prepared [3] and analyzed by inductively coupled plasma mass-spectrometry on an iCAP6300 Duo (Thermo Scientific, USA) optical emission spectrometer with inductively coupled plasma, set to an axial view of the plasma flame.

*Corresponding authors: Albina V. Stepanova, North-Eastern Federal University, the Republic of Sakha, Yakutsk, Russia.

E-mail: anshakova_v@mail.ru

\section{Results and Discussion}

The results obtained from this elemental analysis of the two types of lichen are presented in Table (1). The content of most micro- and macroelements in the studied samples didnot differ much between the two species. In Cetrariacuculata, there are trace amounts of lead and cadmium, but at this level they would not cause any toxic effect in the human body. Their content is considerably lower than the amounts stated in the Sanitary Regulations and Standards (SanPiN).3.2.560-02. Maximum Allowable Concentrations.

\section{Conclusion}

The content of toxic elements and heavy metals in the samples analyzed does not exceed their maximum allowable concentrations and therefore does not preclude the possibility of use of these lichens as a renewable raw material for biotechnology. Indeed, the samples contained 20 macro- and microelements and 9 trace elements that would be valuable in a food source. These include the elements $\mathrm{Fe}, \mathrm{Mg}$, and $\mathrm{Ca}$, required for prevention of deficiency diseases.

\section{Competing interests}

The authors declare that they have no competing interests. 
Table 1.

The micro- and macro element content of thalli of Cladoniarangiferina and Cetrariacuculata

\begin{tabular}{|c|c|c|c|c|c|}
\hline \multirow{2}{*}{ Elements } & Mineral content as percentage of dry weight & \multirow{2}{*}{ Elements } & \multicolumn{2}{|c|}{ Mineral content as percentage of dry weight } \\
\cline { 2 - 5 } & Cladoniarangiferina & Cetrariacuculata & & Cladoniarangiferina & Cetrariacuculata \\
\hline $\mathrm{Al}$ & 0.07090 & 0.17630 & $\mathrm{~Pb}$ & 0.00040 & 0.00140 \\
\hline $\mathrm{Ba}$ & 0.00350 & 0.01420 & $\mathrm{Rb}$ & 0.00330 & 0.01000 \\
\hline $\mathrm{Be}$ & 0.00020 & 0.00020 & $\mathrm{Sc}$ & 0.00004 & 0.00009 \\
\hline $\mathrm{Ca}$ & 3.54440 & 17.7840 & $\mathrm{Si}$ & 0.29140 & 0.68530 \\
\hline $\mathrm{Cd}$ & 0 & 0.00004 & $\mathrm{Sr}$ & 0.00830 & 0.03990 \\
\hline $\mathrm{Ce}$ & 0.00102 & 0.00043 & $\mathrm{Ti}$ & 0.00360 & 0.00770 \\
\hline $\mathrm{Co}$ & 0.00050 & 0.00080 & $\mathrm{~V}$ & 0.00008 & 0.00027 \\
\hline $\mathrm{Cr}$ & 0.00110 & 0.00250 & $\mathrm{Y}$ & 0.00006 & 0.00003 \\
\hline $\mathrm{Cu}$ & 0.03900 & 0.03680 & $\mathrm{Yb}$ & 0.00001 & 0 \\
\hline $\mathrm{Fe}$ & 0.07000 & 0.19750 & $\mathrm{Zn}$ & 0.06740 & 0.11600 \\
\hline $\mathrm{K}$ & 3.94900 & 12.8360 & $\mathrm{Mn}$ & 0.02680 & 0.03970 \\
\hline $\mathrm{La}$ & 0.00007 & 0.00043 & $\mathrm{Na}$ & 2.68240 & 22.7980 \\
\hline $\mathrm{Li}$ & 0.00020 & 0.00130 & $\mathrm{Nd}$ & 0.00280 & 0.00020 \\
\hline $\mathrm{Mg}$ & 2.15820 & 13.7170 & $\mathrm{Ni}$ & 0.00570 & 0.01000 \\
\hline
\end{tabular}

\section{References}

1. Anshkova VV, Stepanova AV, Uvarov DM, Smagulova ASh, Naumova KN, Vasilyev PP, et al. Actoprotective activity of complex biologics based on Lichen thalli and Rhodiola Rosea. Ekologiia Cheloveka. 2015: 5:46-51. [in Russian].
2. Anshakova VV. The mechanochemical technology for producing of biocomplexes based on lichen material. Int $\mathrm{J}$ Biomed. 2012; 3:232-236. [in Russian].

3. Vershinina SE, Vershinin KE, Kravchenko OYu, Chebykin EP, Vodneva EN. Elemental composition of lichen p. Cetraria $\mathrm{ACH}$ from the different regions of Russia. Chemistry of Plant Raw Materials. 2009;1:141-146. [in Russian]. 